\title{
Physiochemical characteristics and therapeutic effects of lyophilized Bee venom and Royal jelly
}

\author{
Sharoba**, A.M.; EL-Tanahi, H.H.; Hafez, H.N.; Hendawy*, H.A. and Yousef, S.Y.A. \\ Food Science Department, Faculty of Agriculture, Benha University. \\ * Anesthesia, Intensive Care and Pain Relief Department, Faculty of Medicine, Suez Canal University \\ **Corresponding author: Dr. Ashraf Sharoba \\ Food Science Department, Faculty of Agriculture, Benha University, Qaluobia, Egypt. \\ E-mail: ashraf_sharoba@yahoo.com \\ Tel. 00201221463079 Fax: 0020132467786
}

\begin{abstract}
This study was investigating the chemical and physical analysis of bee venom and royal jelly before and after lyophlization process and found that the lyophlization process improved the efficiency of the enzymes and active ingredients as a result of low moisture to 5\%. The use of bee venom and royal jelly improved the therapeutic efficiency of some diseases: improving the sexual efficiency, the functions of the kidney and decrease the rate of glucose by using the doses of $500 \mathrm{mg}$ and 1 gram of (1mg of lyophilized bee venom $+500 \mathrm{mg}$ of lyophilized royal jelly $+25 \mathrm{mg}$ honey) / $\mathrm{kg}$ of body weight orally daily for adult male rats for a month. This study showed that the treatment of adult male rats by 1 gram $(1 \mathrm{mg}$ of lyophilized bee venom $+500 \mathrm{mg}$ of lyophilized royal jelly $+25 \mathrm{mg}$ honey) / $\mathrm{kg}$ of body weight orally alone resulted in increasing the weights of the testis and the body of the epididymus, sperm count, testosterone hormone, the percentage of live sperm, and glutathione level, accompanied with decrease in malondialdehyde level and the percentage of sperm abnormality. The oral administration of $(1 \mathrm{mg}$ of lyophilized bee venom $+500 \mathrm{mg}$ of lyophilized royal jelly $+25 \mathrm{mg}$ honey) in doses of $500 \mathrm{mg}$ and $1 \mathrm{~g} / \mathrm{kg}$ body weight today for one month increased urea concentration in serum and decreased in urine, urea clearance in urine was also decreased as compared to control group. (1 mg of lyophilized bee venom $+500 \mathrm{mg}$ of lyophilized royal jelly $+25 \mathrm{mg}$ honey) in a dose of $1 \mathrm{~g} / \mathrm{kg}$ body weight daily decreased serum, urine and creatinine levels. Decrease in serum glucose level was also observed when the test animals were treated with ( $1 \mathrm{mg}$ of lyophilized bee venom $+500 \mathrm{mg}$ of lyophilized royal jelly $+25 \mathrm{mg}$ honey) in a dose of 500mg and $1 \mathrm{~g} / \mathrm{kg}$ body weight daily. Remarkable for one month was showed increasing in body weight of adult rats that treated with $1 \mathrm{~g}$ ( $1 \mathrm{mg}$ of lyophilized bee venom $+500 \mathrm{mg}$ of lyophilized royal jelly $+25 \mathrm{mg}$ honey) $/ \mathrm{kg}$ of body weight compared with control group. This study recommended that using mixtures of lyophilized bee venom and royal jelly which are dissolved in honey as therapy of sexual efficiency, kidney and sugar diseases.
\end{abstract}

Keywords: Bee venom, royal jelly, sexual efficiency, therapeutic efficiency.

\section{Introduction:}

Eros, stung by a bee, ran away and cried for plea: Venus, mother, I cry, please help me or I'll die What a terrible disgracea dragon bit me on my face Venus comforting her son Speaking with a mocking fun The little bee's tiny sting Is for you an earnest thing But more painful and real hard are your stings in human's heart Anacreontean songs, 6 BC

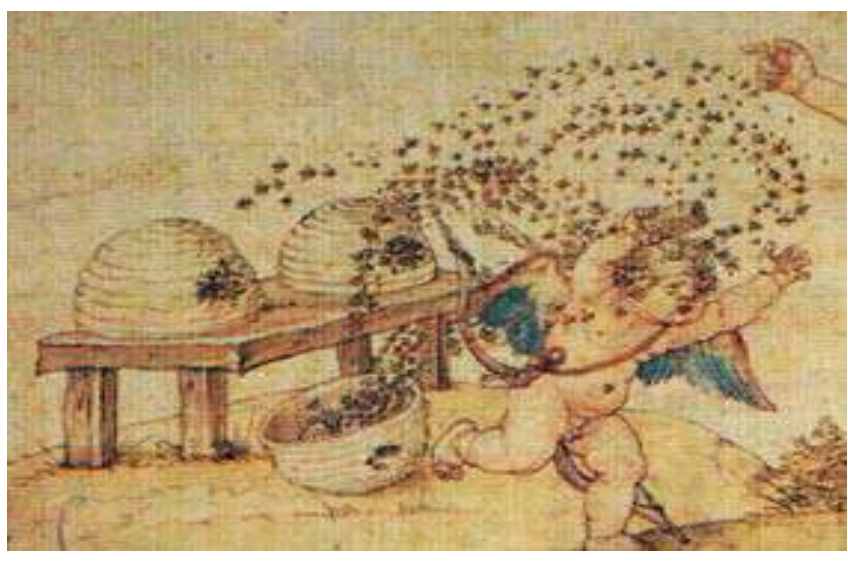

Venus, Eros and the bees, by A. Dürer, 1514
It was difficult for Eros to bear the bee stings which like his arrows and both painful and healing.... . Already in the early ancient civilizations knew about the healing found virtues in the painful bee stings. Bee stings are probably one of the first natural cures for arthritis. In the ancient civilization of China, India, Egypt, Babylon and Greece bee venom was used for apitherapy (Urtubey, 2005). 
Whether the humans began keeping bees because of the healing effects of their stings or to get honey, or for both reasons, we do not know (http://www.beehexagon.net (2012). Also, the use of honey and other bee products in human treatments traced back thousands of years and healing properties are included in many religious texts including the Veda, Bible and Quran (El-Banby, 1994). Apitherapy is the use of honey bee products for medical purposes, this include bee venom, raw honey, royal jelly, pollen, propolis and beeswax. Whereas bee venom therapy is the use of live bee stings (or inject able venom) to treat various diseases such as arthritis (Beck, 1999), rheumatoid arthritis, multiple sclerosis (MS), lupus, sciatica, low back pain, and tennis elbow to name a few. It refers to any use of venom to assist the body in healing itself. Bee venom contains at least 18 pharmacologically active components including various enzymes, peptides and amines (Habermann and Jentsch, 1999).

Sulfur is believed to be the main element in inducing the release of cortisol from the adrenal glands and in protecting the body from infections. Contact with bee venom produces a complex cascade of reactions in the human body. The bee venom is safe for human treatments, the median lethal dose $\left(\mathrm{LD}_{50}\right)$ for an adult human is $2.8 \mathrm{mg}$ of venom per $\mathrm{kg}$ of body weight (Crane, 1990), for example a person weighing $60 \mathrm{~kg}$ has a $50 \%$ chance of surviving injections totaling $168 \mathrm{mg}$ of bee venom (Tumanov and Osipova, 1996). Assuming each bee injects all its venom and no stings are quickly removed at a maximum of $0.3 \mathrm{mg}$ venom per sting, 560 stings could well be lethal for such a person. For a child weighing $10 \mathrm{~kg}$, as little as 93.33 stings could be fatal. However, most human deaths result from one or few bee stings due to allergic reactions, heart failure or suffocation from swelling around the neck or the mouth. Compared with other human diseases, accidents and other unusual cases, the bee venom is very safe for human treatments (Bogdanov, 2011a).

Bee venom: Honeybee venom is produced by two glands associated with the sting apparatus of worker bees. Its production increases during the first two weeks of the adult worker's life and reaches a maximum when the worker bee becomes involved in hive defenses and foraging. It diminishes as the bee gets diminishes as the bee gets older.

Royal jelly: is a thick, extremely nutrition, milky white, creamy liquid secreted by the hypo pharyngeal glands of worker bees (Apis mellifera) in relation to sexual determination of the bee (Antinelli et al., 2003). Considered as the major cause for difference between queen and bee workers, royal jelly is appreciated as a dietary complement because of its composition. Royal jelly is an essential food for the queen bee larvae and the queen herself. All larvae fed royal jelly for three days, but the queen bee eats royal jelly exclusively which makes her fertile and able to live to seven years. Queen bees will produce
2000 eggs per day, with each day brood equal to 2.5 times her body weight (Leung et al., 1997). In contrast, worker bees are sterile and live just seven to eight weeks. Royal jelly contains considerable amounts of proteins, amino acids including 8 essential amino acids, hormone rich substance (testosterone has been identified in extremely small quantities in royal jelly about $0.012 \mathrm{~g} / \mathrm{g}$ fresh weight http://www.goldinnature.com/apitherapylinks.ht ml (2004), royal jelly also contains lipid, sugars, vitamin A, C, D \& E, minerals are in descending order: ( $\mathrm{K}, \mathrm{Ca}, \mathrm{Na}, \mathrm{Zn}, \mathrm{Fe}, \mathrm{Cu}$ and $\mathrm{Mn}$ ), enzymes antibiotic components and an abundance of nucleic acid-DNA and RNA.

Gelatin, one of the precursors of collagen, is also found in royal jelly, collagen is a powerful anti-aging element that helps preserve the youth of the body (Compston, 2001). Gelatin is known to have several diverse physiological and pharmacological functions, these include vasodilative, hypotensive, ant hypercholesterolemia, and anti-tumor activities (Narita et al. 2006). Royal jelly has been found to be of great help in boosting the body resistance to the harmful side effect of chemotherapy and radiotherapy http://www.apitherapy.org (2001). Also, contains gamma globulin, which helps the immune system to fight infections. It also contains sterols, phosphorous compounds and acetylcholine, which are needed to transmit nerve messages from cell to cell.

Al-Taei (2003) demonstrated that, the reactive oxygen species produced by administration of hydrogen peroxide are responsible for the pathophysiological changes of the male reproductive system and induced defect in the histophysiological aspect of this system in rats.

Polyunsaturated fatty acids and phospholipids are key constituents in the sperm cell membrane and are highly susceptible to oxidative damage. Sperm produce controlled concentrations of reactive oxygen species, such as the superoxide anion, hydrogen peroxide, and nitric oxide, which are needed for fertilization; however, high concentrations of these free radicals can directly damage sperm cells (Ebisch et al., 2006). On another hand, the active ingredients in bee venom and royal jelly are active due to lyophlization, Bogdanov (2011b).

Honey: Honey is the natural sweets substance produced by honeybees from the nectar of blossoms or from the secretion of living parts of plants or excretions of plant sucking insects on the living parts of plants, which honeybees collect, transform and combine with specific substances of their own, store and leave in the honey comb to ripen and mature. This is the general definition of honey in the Codex Alimentarius (1989).

The current study was aimed to investigate effect the administration different concentrations $1 \mathrm{~g}, 500$ $\mathrm{mg}$ of $(1 \mathrm{mg}$ bee venom $+500 \mathrm{mg}$ royal jelly $+25 \mathrm{mg}$ honey) orally for one month daily to the male adult 
rats induced oxidative stress by hydrogen peroxide on sexual efficacy and glutathione, malondialdehyde levels, and to study the effect of this administration on the glucose level and serum in rats.

\section{Materials and methods:}

\section{Materials}

Bee venom, royal jelly and honey were obtained as pure substance from GHADA Company - Borgalarb- Alexandria-Egypt, in January, February, April, June, September, October and December 2013.

\section{Bee venom extraction:}

The venom collection was conducted by Moshtohor device according to Khattab (1997).

\section{Lyophlization of bee venom:}

Add $1 \mathrm{ml}$ of distilled water per 1 gram of raw bee venom and filtering by nomination paper 0.02 to get rid of impurities. Then the venom was freezing at $-50^{\circ} \mathrm{C}$ for 24 hours and put in lyophlization device (invented by the researcher), at $10^{\circ} \mathrm{C}$ and a pressure at -0.8 bar to reach to sublimation process for 48 hours, finally, getting lyophilized bee venom as a powder with a suitable moisture content $6.0-8.0 \%$.

\section{Lyophlization of royal jelly:}

Add $5 \mathrm{ml}$ of $13 \%$ ethanol per 1 gram of raw royal jelly then freezing at $-70^{\circ} \mathrm{C}$ for 24 hours. After that, put royal jelly in lyophlization device (invented by the researcher), at $-10^{\circ} \mathrm{C}$ and a pressure at -0.8 bar to reach to sublimation process for 48 hours. Finally, getting a lyophilized royal jelly as a powder with suitable moisture content $3.41-6.62 \%$. Then store in dark jars at room temperature $\left(25^{\circ} \mathrm{C}-30^{\circ} \mathrm{C}\right)$. After that dissolve $1 \mathrm{mg}$ of lyophilized bee venom + $500 \mathrm{mg}$ of lyophilized royal jelly in $25 \mathrm{mg}$ bee honey, according to DGHCP (2002).

\section{Methods:}

\section{Chemical analysis:}

Moisture, crude protein, lipid and ash contents were determined according to the methods described in AOAC (2005).

Fructose, glucose, sucrose, 10-hydroxy-2deconoic acid, melitine, phospholipids $\mathrm{A}$ and hyaluronidase were determined according to the method by $\mathrm{H} \mathrm{P} \mathrm{L} \mathrm{C}$ analysis.

$\mathrm{pH}$ value of device model MA 5736, Metrel, Iskra, Slovenia was determined according to the method described by AOAC (2005).

\section{Animal Experimental:}

Sixty three adult male albino rats were obtained from the animal house of the Medical Research Center, Alexandria, was aged 2-3 month and weights ranged from 220 - 280g. They were housed in polypropylene cages under controlled condition of temperature $\left(24-26^{\circ} \mathrm{C}\right)$ and lighting (12hours light/12hours dark). The rats were supplied with standard diet and tap water.

The adult male rats were randomly divided into six groups. The first three groups were 12 rats/group and the second three groups were 9 rats/ group. The first group received tap water serve as control. The second group received $0.5 \%$ hydrogen peroxide $\left(\mathrm{H}_{2} \mathrm{O}_{2}\right)$ daily in drinking water for one month to be compared with the sample (Abdul-Rahman, 1995). The third group received $0.5 \%\left(\mathrm{H}_{2} \mathrm{O}_{2}\right)$ daily in drinking water for one month concomitant with $(1 \mathrm{mg}$ of lyophilized bee venom+500mg of lyophilized royal jelly $+25 \mathrm{mg}$ honey) at $1 \mathrm{~g} / \mathrm{kg}$ body weight dissolved in distilled water and given daily for one month orally by gavages needle (Mishima et al ., 2005). The fourth, fifth and sixth groups received (1mg of lyophilized bee venom $+500 \mathrm{mg}$ of lyophilized royal jelly $+25 \mathrm{mg}$ honey) at a dose $1 \mathrm{~g} / \mathrm{kg}$ body weight orally daily. The weight of rats recorded weekly. At the end of experiment blood samples were collected into clean dry centrifuge tubes allowed to clot, serum separated after centrifugation at $1500 \mathrm{rpm}$ for 15 minute for testosterone hormone assay, using Enzyme Linked Immune sorbent Assay (ELISA) (BioCheck Company, USA). Rats were sacrificed by ether administration. The abdominal cavity was then opened; the weight of testis, epididymal, seminal vesicles and prostate were recorded. The test is placed in ice normal saline for glutathione estimation using Moron method as described by malondialdehyde (MDA) estimation using Gilbert method. The epididymis was dissected out, sectioned and immediately the content of the tail of each epididymis was squeezed gently in clean watch glass diluted 10 times with isotonic solution of sodium citrate $2.9 \%$ at $37^{\circ} \mathrm{C}$, take one drop from isotonic solution on slide and added one drop of eosin nigrosin stain and made smear, this technique was used for the percentage of live/dead and for morphological abnormal sperms to be counted (AlSadi, 2001). The content of the head of epididymis was squeezed immediately in clean watch glass contained $9.8 \mathrm{ml}$ buffer formalin with $0.1 \mathrm{ml}$ eosin $5 \%$, this was used for counting the sperm concentration using hemocytometric technique (Bearden et al., 2004), and comparing with the control group, (1mg of lyophilized bee venom $+500 \mathrm{mg}$ of lyophilized royal jelly $+25 \mathrm{mg}$ honey) in dose of 50 and $100 \mathrm{mg} / \mathrm{kg}$ body weight daily which obtained on it the level of creatinine in serum and urine, finally we obtained glucose level in serum and urine to rats which administrated by 50 and 100 $\mathrm{mg} / \mathrm{kg}$ body weight of (1mg of lyophilized bee venom $+500 \mathrm{mg}$ of lyophilized royal jelly $+25 \mathrm{mg}$ honey). 


\section{Statistical analysis:}

Data were analyzed statistically using one way analysis of variance as determined by Petrie and Watson (1999).

\section{Results and discussion:}

a. Effect of Lyophlization on the chemical characteristic of royal jelly and bee venom: a.1. Chemical characteristic of royal jelly

According to table (1) we can recognized that the reduction in moisture content of royal jelly samples was ranged between $92-95 \%$ after lyophilized the samples. This was in accordance with previous scientific researches (Messia et al., 2005 and Bogdanov (2011a)).

The proportion of the proteins in royal jelly was large. From Table (1), the average value of total protein was increased from $8.62-9.14 \%$ to $25.90-$ $27.44 \%$ after lyophlization. Similar results were reported by Simúth (2001) and Kim et al., (2010).

The same trend was observed with royal jelly total lipids in Table (1). There was increasing in the total lipids average $5.19-5.72 \%$ to $8.40-9.10 \%$ after lyophlization. This is in accordance with Sabatini et al., (2009) and Kodai et al.,(2007).

The concentration of the most abundant sugars fructose was ranged between $7.92-8.11 \%$ and after lyophlization ranged between $5.11-16.39 \%$, glucose was $5.53-5.81 \%$ after lyophlization ranged from $10.21-10.98 \%$ and sucrose ranged from $0.52-$ $0.61 \%$ and after lyophlization ranged between $1.20-$ $1.32 \%$ (see Table 1). These values are comparable with the sugar levels reported in the literature (Simúth, 2001and Sabatini et al., 2009).

There were some variations in values for individual samples which was normal for organic products.
According to Simúth (2001), the average level of glucose in lyophilized royal jelly (10.21 $10.98 \%)$ was higher than that of fructose (5.11 16.39\%). Sabatini et al., (2009) reported that fructose was prevalent to glucose which was also confirmed in our study. Sucrose is always present but in highly variable concentrations. Thus the amount of analyzed royal jelly samples was insufficient to draw conclusions about the prevalence of glucose or fructose.

Royal jelly was highly acidic with pH $3.4-3.90$ from Table (1), after lyophlization $\mathrm{pH}$ slightly decreased and became $3.29-3.81$. The results were in accordance with Lercker (2003) and Scarselli $\boldsymbol{e t}$ al.,(2005)

Most of the organic acids are free with rather unusual structure rarely encountered in nature, monoand dihydroxy acids and dicarboxylic acids with 8 and 10 carbon atoms (Lercker et al., 1993), the main acid being 10-hydroxy-2decenoic acid, which was antibacterial and immune activating (Bachanova $\boldsymbol{e t}$ al., 2002), immune-modulating, anti-cancer (Dzopalic et al., 2011), anti-diabetes (Okuda et al.,1998), collagen promoting and skin protecting, anti-ulcer (Fang,1994), facilitates differentiation of brain cells (Hattori et al., 2007) antidepressant in mice experiments (Ito et al., 2012), promotes endothelial health, antihypertensive, antihyperlipoidemia (Izuta et al., 2009) estrogenic(Matsui et al., 2002) anti-rheumatic and activation of TRPA1 and TRPV1 (induces thermogenesis and energy expenditure enhancement) (Terada et al., 2011).

HAD was ranged between $2.71-2.91 \%$ and after lyophlization it became $8.13-8.70 \%$ according to (Bogdanov (2011a)).

Table 1. Chemical composition of fresh and lyophilized royal jelly (Mean \pm SE)

\begin{tabular}{|c|c|c|c|c|c|c|c|c|}
\hline \multirow[t]{3}{*}{ Parameters } & \multicolumn{8}{|c|}{ Royal Jelly } \\
\hline & \multicolumn{2}{|c|}{ (February) } & \multicolumn{2}{|c|}{ (April) } & \multicolumn{2}{|c|}{ (June) } & \multicolumn{2}{|c|}{ (September) } \\
\hline & $\mathbf{A}$ & B & $\mathbf{A}$ & B & $\mathbf{A}$ & B & $\mathbf{A}$ & B \\
\hline Moisture\% & $66.28 \pm$ & $5.27 \pm$ & $64.17 \pm$ & $3.41 \pm 1.66$ & $67.21 \pm$ & 5.11 & $68.15 \pm$ & 5.62 \\
\hline Moisture\% & 0.01 & 0.01 & 0.01 & & 0.01 & \pm 0.01 & 0.01 & \pm 0.01 \\
\hline PH & $3.87 \pm 0.01$ & $3.62 \pm 0.01$ & $3.90 \pm 0.06$ & $3.81 \pm 0.01$ & $3.60 \pm 0.06$ & $3.50 \pm 0.06$ & $3.40 \pm 0.06$ & $3.29 \pm 0.01$ \\
\hline Protein \% & $9.14 \pm 0.03$ & $\begin{array}{c}27.44 \pm \\
0.01\end{array}$ & $8.92 \pm 0.01$ & $\begin{array}{c}26.41 \pm \\
0.01\end{array}$ & $8.62 \pm 0.01$ & $\begin{array}{c}25.90 \pm \\
0.06\end{array}$ & $\begin{array}{c}8.91 \pm \\
0.01\end{array}$ & $\begin{array}{c}26.91 \pm \\
0.01\end{array}$ \\
\hline Fructose \% & $8.11 \pm 0.01$ & $\begin{array}{c}16.39 \pm \\
0.01\end{array}$ & $7.92 \pm 0.01$ & $\begin{array}{c}15.11 \pm \\
0.01 \\
\end{array}$ & $7.95 \pm 0.01$ & $\begin{array}{c}16.12 \pm \\
0.01 \\
\end{array}$ & $7.99 \pm 0.01$ & $\begin{array}{c}16.11 \pm \\
0.01 \\
\end{array}$ \\
\hline Glucose \% & $5.53 \pm 0.01$ & $\begin{array}{c}10.21 \pm \\
0.01\end{array}$ & $5.71 \pm 0.01$ & $\begin{array}{c}10.61 \pm \\
0.01 \\
\end{array}$ & $5.62 \pm 0.01$ & $\begin{array}{c}10.41 \pm \\
0.01 \\
\end{array}$ & $5.81 \pm 0.01$ & $\begin{array}{c}10.98 \pm \\
0.01 \\
\end{array}$ \\
\hline Sucrose \% & $\begin{array}{c}0.55 \pm \\
0.01\end{array}$ & $1.21 \pm 0.01$ & $0.52 \pm 0.01$ & $1.20 \pm 0.01$ & $0.61 \pm 0.01$ & $\begin{array}{c}1.32 \pm \\
0.01\end{array}$ & $0.58 \pm 0.01$ & $1.28 \pm 0.01$ \\
\hline Total sugar\% & $14.19 \pm 0.01$ & $27.81 \pm 0.01$ & $14.15 \pm 0.01$ & $26.92 \pm 0.01$ & $14.18 \pm 0.01$ & $27.85 \pm 0.01$ & $14.38 \pm 0.01$ & $28.37 \pm 0.01$ \\
\hline Ash\% & $0.71 \pm 0.01$ & $2.51 \pm 0.01$ & $0.62 \pm 0.01$ & $2.12 \pm 0.01$ & $0.69 \pm 0.01$ & $2.41 \pm 0.01$ & $0.65 \pm 0.01$ & $2.45 \pm 0.01$ \\
\hline $\begin{array}{l}\text { 10-hydroxy- } \\
\text { 2deconoic acid \% }\end{array}$ & $2.71 \pm 0.01$ & $8.13 \pm 0.01$ & $2.86 \pm 0.06$ & $8.38 \pm \mathbf{0 . 0 1}$ & $2.91 \pm 0.06$ & $8.70 \pm 0.06$ & $2.82 \pm 0.06$ & $8.56 \pm 0.01$ \\
\hline Lipids \% & $5.72 \pm 0.01$ & $9.10 \pm 0.06$ & $5.59 \pm 0.04$ & $8.92 \pm 0.01$ & $5.32 \pm 0.01$ & $8.40 \pm 0.06$ & $5.19 \pm 0.01$ & $8.60 \pm 0.06$ \\
\hline
\end{tabular}

a.2 Chemical characteristics of bee venom
Bee venom is a transparent liquid dries up easily even at room temperature, odorless, ornamental 
pungent smell, a bitter taste, hydrolytic blend of proteins with basic $\mathrm{pH}(4.5-5.5)$ that is used by bees for defense (Schmidt and Buchmann (1999). When coming into contact with mucous membranes or eyes, it causes considerable burning and irritation. Bee venom is soluble in water and insoluble in alcohol and ammonium sulfate. When it comes in contact with air it forms grayish-white crystals. Lyophlized venom takes on a light yellow color and some commercial preparations are brown, thought to be due to oxidation of some of the venom proteins. Bee venom contains a number of very volatile compounds which are easily lost during collection, it is considered a rich source of enzymes, peptides and biogenic amines, and it is specific weight (1.1331).The venoms of most stinging insects including honey bees consisted of enzymes, protein, peptides, and a verity of smaller molecules. The pharmacological and biochemical activities of the various stinging insect venoms remarkably convergent. Most venom induces immediate pain. From the results in Table (2), the phospholipids was ranged from $1.20-1.50 \%$ and became $9.60-$ $11.20 \%$ after lyophlization, hyaluronidase was ranged from $0.28-0.32 \%$ after lyophlization it became $2.0-2.20 \%$ and is capable of destroying red blood cells. Most hymenopterous venoms also contain low molecular weight peptides (Norman et al., (2011)). On the otherhand lyophilized bee venom content of melitine was ranged between 52.0 $56.0 \%$ and in accordance with Bogdanov (2011b).

Table 2. Chemical composition of fresh and lyophlized bee venom (Mean \pm SE).

\begin{tabular}{|c|c|c|c|c|c|c|c|c|}
\hline \multirow[t]{3}{*}{ Parameters } & \multicolumn{8}{|c|}{ Bee Venom } \\
\hline & \multicolumn{2}{|c|}{ (January) } & \multicolumn{2}{|c|}{ (April) } & \multicolumn{2}{|c|}{ (October) } & \multicolumn{2}{|c|}{ (December) } \\
\hline & $\mathbf{A}$ & B & $\mathbf{A}$ & B & $\mathbf{A}$ & B & $\mathbf{A}$ & B \\
\hline Moisture \% & $\begin{array}{c}90.0 \pm \\
0.58\end{array}$ & $\begin{array}{l}8.0 \pm \\
0.06\end{array}$ & $\begin{array}{c}86.0 \pm \\
0.58\end{array}$ & $\begin{array}{l}6.0 \pm \\
0.06 \\
\end{array}$ & $\begin{array}{c}86.0 \pm \\
0.58\end{array}$ & $\begin{array}{l}6.0 \pm \\
0.06 \\
\end{array}$ & $\begin{array}{c}87.0 \pm \\
0.58\end{array}$ & $\begin{array}{c}6.20 \pm \\
0.06\end{array}$ \\
\hline Melitine \% & $\begin{array}{c}6.20 \pm \\
0.06\end{array}$ & $\begin{array}{c}52.0 \pm \\
0.58\end{array}$ & $\begin{array}{c}7.50 \pm \\
0.06\end{array}$ & $\begin{array}{c}55.0 \pm \\
0.58\end{array}$ & $\begin{array}{c}7.50 \pm \\
0.06\end{array}$ & $\begin{array}{c}55.0 \pm \\
0.58\end{array}$ & $\begin{array}{c}7.60 \pm \\
0.06\end{array}$ & $\begin{array}{c}56.0 \pm \\
0.58\end{array}$ \\
\hline Phospholipids A \% & $\begin{array}{c}1.20 \pm \\
0.06\end{array}$ & $\begin{array}{c}9.60 \pm \\
0.06\end{array}$ & $\begin{array}{c}1.50 \pm \\
0.06\end{array}$ & $\begin{array}{c}10.98 \pm \\
0.01\end{array}$ & $\begin{array}{c}1.50 \pm \\
0.06\end{array}$ & $\begin{array}{c}11.20 \pm \\
0.06\end{array}$ & $\begin{array}{c}1.50 \pm \\
0.06\end{array}$ & $\begin{array}{c}11.10 \pm \\
0.06\end{array}$ \\
\hline Hyaluronidase \% & $\begin{array}{c}0.28 \pm \\
0.01\end{array}$ & $\begin{array}{c}2.0 \pm \\
0.06\end{array}$ & $\begin{array}{c}0.31 \pm \\
0.01\end{array}$ & $\begin{array}{c}2.10 \pm \\
0.06\end{array}$ & $\begin{array}{c}0.32 \pm \\
0.01\end{array}$ & $\begin{array}{c}2.20 \pm \\
0.06\end{array}$ & $\begin{array}{c}0.30 \pm \\
0.01\end{array}$ & $\begin{array}{c}2.10 \pm \\
0.06\end{array}$ \\
\hline Ash \% & $\begin{array}{c}0.06 \pm \\
0.01\end{array}$ & $\begin{array}{c}0.46 \pm \\
0.01\end{array}$ & $\begin{array}{c}0.07 \pm \\
0.01\end{array}$ & $\begin{array}{c}0.50 \pm \\
0.01\end{array}$ & $\begin{array}{c}0.07 \pm \\
0.01\end{array}$ & $\begin{array}{c}0.51 \pm \\
0.01\end{array}$ & $\begin{array}{c}0.07 \pm \\
0.01\end{array}$ & $\begin{array}{c}0.51 \pm \\
0.01\end{array}$ \\
\hline Total sugar \% & $\begin{array}{c}0.31 \pm \\
0.01\end{array}$ & $\begin{array}{c}1.90 \pm \\
0.06\end{array}$ & $\begin{array}{c}0.36 \pm \\
0.01\end{array}$ & $\begin{array}{c}2.10 \pm \\
0.06\end{array}$ & $\begin{array}{c}0.34 \pm \\
0.01\end{array}$ & $\begin{array}{l}2.0 \pm \\
0.06\end{array}$ & $\begin{array}{c}0.34 \pm \\
0.01\end{array}$ & $\begin{array}{l}2.0 \pm \\
0.06\end{array}$ \\
\hline
\end{tabular}

A: Fresh bee venom.

B: Lyophlized bee venom.

b. Effect of treatment by royal jelly and bee venom on body weight:

From the data in Table (3) demonstrated there was no differences between groups in the body weight after one, two and three weeks of treatment.
After three weeks of treatment the body weight was increased compared with the group which was treated with $\mathrm{H}_{2} \mathrm{O}_{2}$ and the control group. Antinelli et al (2003).

Table 3. Effect the treatment of $1 \mathrm{~g}$ ( $1 \mathrm{mg}$ of lyophilized bee venom $+500 \mathrm{mg}$ of lyophilized royal jelly $+25 \mathrm{ml}$ honey)/kg of body weight orally on body weights in rats receiving hydrogen peroxide for one month (Mean $\pm \mathrm{SE})$.

\begin{tabular}{ccccc}
\hline Treated animals & Weight (zero time) & $\begin{array}{c}\text { Weight after one } \\
\text { week }\end{array}$ & $\begin{array}{c}\text { Weight after two } \\
\text { weeks }\end{array}$ & $\begin{array}{c}\text { Weight after three } \\
\text { weeks }\end{array}$ \\
\hline Control & $270.5 \pm 10.64$ & $246.2 \pm 11.91$ & $273.5 \pm 24.4$ & $299.5 \pm 10.1$ \\
\hline $\mathbf{1}$ & $228.5 \pm 20.34$ & $228.2 \pm 19.70$ & $238.5 \pm 24.6$ & $287.2 \pm 21.6$ \\
\hline $\mathbf{2}$ & $263.0 \pm 8.09$ & $223.5 \pm 20.01$ & $235.2 \pm 21.9$ & $286.2 \pm 14.3$ \\
\hline $\mathbf{3}$ & $265.0 \pm 23.47$ & $250.2 \pm 17.06$ & $247.0 \pm 26.5$ & $305 \pm 34.07$ \\
\hline
\end{tabular}

1: Hydrogen peroxide $(0.5 \%)$ in drinking water for one month.

2: Hydrogen peroxide $(0.5 \%)$ in drinking water for one month $)+1 \mathrm{~g}(1 \mathrm{mg}$ of lyophilized bee venom $+500 \mathrm{mg}$ of lyophilized royal jelly $+25 \mathrm{ml}$ honey) $/ \mathrm{kg}$ of body weight orally for one month.

3: $1 \mathrm{~g}(1 \mathrm{mg}$ of lyophilized bee venom $+500 \mathrm{mg}$ of lyophilized royal jelly $+25 \mathrm{ml}$ honey $) / \mathrm{kg}$ of body weight orally for one month.

C. Effect of treatment by royal jelly and bee venom on increase fertility and efficiency nationality:

Data in Table (4) showed that, the administration by hydrogen peroxide $(0.5 \%)$ in drinking water for one month did not affect the weight of testis, epididymis(head, body, and tail), prostate and seminal vesicles compared with control group value, while the administration by hydrogen peroxide $(0.5 \%)$ in drinking water for $(1 \mathrm{month})+1 \mathrm{~g}(1 \mathrm{mg}$ of 
lyophilized bee venom $+500 \mathrm{mg}$ of lyophilized royal jelly $+25 \mathrm{ml}$ honey ) $/ \mathrm{kg}$ of body weight orally for one month were a companied by increasing in the weight of testis and body of epididymis, whereas no changes in the weight of head and tail of epididymus, prostate and seminal vesicles compared with hydrogen peroxide group. On the other hand, the administration by (1mg of lyophilized bee venom +
$500 \mathrm{mg}$ of lyophilized royal jelly $+25 \mathrm{ml}$ honey) $/ \mathrm{kg}$ of body weight orally for one month increased the weight of testis and body of epididymis, whereas no changes in the weight of head and tail of epididymus, prostate and seminal vesicles compared with hydrogen peroxide group, and this results were in agreement with those obtained by Strum et al. (2002) and Abreu et al. (2000).

Table 4. Effect the treatment of $1 \mathrm{~g}$ ( $1 \mathrm{mg}$ of lyophilized bee venom $+500 \mathrm{mg}$ of lyophilized royal jelly $+25 \mathrm{ml}$ honey) $/ \mathrm{kg}$ of body weight orally on the weight of the testis, epididymis (head, body, tail) prostate and seminal vesicle in rats receiving hydrogen peroxide for one month (Mean $\pm \mathrm{SE}$ ).

\begin{tabular}{ccccccc}
\hline Treated animals & $\begin{array}{c}\text { Testis } \\
\text { mg/100g } \\
\text { B.Wt. }\end{array}$ & $\begin{array}{c}\text { Head of } \\
\text { epididymus } \\
\text { mg/100g } \\
\text { B.Wt }\end{array}$ & $\begin{array}{c}\text { Body of } \\
\text { epididymus } \\
\mathbf{m g / 1 0 0 g} \\
\text { B.Wt }\end{array}$ & $\begin{array}{c}\text { Tail of } \\
\text { epididymus } \\
\text { mg/100g } \\
\text { B.Wt }\end{array}$ & $\begin{array}{c}\text { Prostate } \\
\mathbf{m g} / \mathbf{1 0 0 g} \\
\mathbf{B . W t}\end{array}$ & $\begin{array}{c}\text { Seminal } \\
\text { vesicle } \\
\mathbf{m g} / \mathbf{1 0 0 g} \\
\mathbf{B . W t}\end{array}$ \\
\hline Control & $473.4 \pm 27.7$ & $79.2 \pm 4.2$ & $21.1 \pm 0.9$ & $93.2 \pm 7.4$ & $447.5 \pm 44.2$ & $100.9 \pm 5.9$ \\
\hline $\mathbf{1}$ & $501.5 \pm 10.8$ & $85.0 \pm 3.9$ & $20.8 \pm 0.6$ & $92.9 \pm 5$ & $431.35 \pm 35.3$ & $108.9 \pm 7.4$ \\
\hline $\mathbf{2}$ & $604.9 \pm 212$ & $89.4 \pm 5.5$ & $23.7 \pm 0.3$ & $93.4 \pm 2.9$ & $455.3 \pm 33.2$ & $99.9 \pm 6$ \\
\hline $\mathbf{3}$ & $636.1 \pm 21.7$ & $76.5 \pm 4.1$ & $24.1 \pm 0.3$ & $90.4 \pm 1.5$ & $427.1 \pm 26.7$ & $105.7 \pm 6.4$ \\
\hline
\end{tabular}

1: Hydrogen peroxide $(0.5 \%)$ in drinking water for one month.

2: Hydrogen peroxide $(0.5 \%)$ in drinking water for one month $+1 \mathrm{~g}(1 \mathrm{mg}$ of lyophilized bee venom $+500 \mathrm{mg}$ of lyophilized royal jelly $+25 \mathrm{ml}$ honey) $/ \mathrm{kg}$ of body weight orally for one month.

3: $1 \mathrm{~g}(1 \mathrm{mg}$ of lyophilized bee venom $+500 \mathrm{mg}$ of lyophilized royal jelly $+25 \mathrm{ml}$ honey)/kg of body weight orally for one month.

Data in Table (5) that revealed that there was decrease in the sperm count in hydrogen peroxide group compared with control group, while, treatment with $1 \mathrm{~g}$ ( $1 \mathrm{mg}$ of lyophilized bee venom $+500 \mathrm{mg}$ of lyophilized royal jelly $+25 \mathrm{ml}$ honey) $/ \mathrm{kg}$ of body weight orally and hydrogen peroxide caused increase in sperm count compared with hydrogen peroxide group and approximately returned to the normal control value( 1.43 ). Data in the same Table showed increase in the sperm count by $1 \mathrm{~g}$ (1mg of lyophilized bee venom $+500 \mathrm{mg}$ of lyophilized royal jelly $+25 \mathrm{ml}$ honey) $/ \mathrm{kg}$ of body weight orally treated group compared with hydrogen peroxide group, and $1 \mathrm{~g}$ ( $1 \mathrm{mg}$ of lyophilized bee venom $+500 \mathrm{mg}$ of lyophilized royal jelly $+25 \mathrm{ml}$ honey) $/ \mathrm{kg}$ of body weight orally concomitantly with hydrogen peroxide group. Also, data in the same Table demonstrated that there was decrease in glutathione level in hydrogen peroxide group compared with control group, while administration of $1 \mathrm{~g}$ (1mg of lyophilized bee venom $+500 \mathrm{mg}$ of lyophilized royal jelly $+25 \mathrm{ml}$ honey) $/ \mathrm{kg}$ of body weight orally with or without hydrogen peroxide caused increase in the glutathione level compared with hydrogen peroxide group. On the other hand, data in Table (5) showed that increase in malondialdehyde level in hydrogen peroxide group compared with control group while treatment with $1 \mathrm{~g}(1 \mathrm{mg}$ of lyophilized bee venom $+500 \mathrm{mg}$ of lyophilized royal jelly $+25 \mathrm{ml}$ honey) $/ \mathrm{kg}$ of body weight orally concomitant with hydrogen peroxide were no affect in the malondialdehyde level, but the treatment with $1 \mathrm{~g}$ (1mg of lyophilized bee venom $+500 \mathrm{mg}$ of lyophilized royal jelly $+25 \mathrm{ml}$ honey) $/ \mathrm{kg}$ of body weight orally alone caused decrease in malondialdehyde level, WHO (2002) and Krell (1996).

Table 5. Effect of the treatment of $1 \mathrm{~g}$ ( $1 \mathrm{mg}$ of lyophilized bee venom $+500 \mathrm{mg}$ of lyophilized royal jelly $+25 \mathrm{ml}$ honey)/kg of body weight orally on sperm count, glutathione, and malonaldehyde levels in the rats receiving hydrogen peroxide for one month (Mean \pm SE).

\begin{tabular}{cccc}
\hline Treated animals & Sperm concentration $\mathbf{x 1 0}$ & $\begin{array}{c}\text { Glutathione } \\
\boldsymbol{\mu m} / \mathbf{g}\end{array}$ & $\begin{array}{c}\text { Malonaldehyde } \\
\mathbf{n m} / \mathbf{g}\end{array}$ \\
\hline Control & $1.4320 \pm 0.02$ & $1.04 \pm 0.02$ & $264.82 \pm 12.48$ \\
\hline $\mathbf{1}$ & $0.80 \pm 0.02$ & $0.59 \pm 0.02$ & $311.0 \pm 17.6$ \\
\hline $\mathbf{2}$ & $1.3440 \pm 0.13$ & $1.23 \pm 0.14$ & $233.9 \pm 14.3$ \\
\hline $\mathbf{3}$ & $1.6260 \pm 0.02$ & $1.26 \pm 0.02$ & $219.7 \pm 5.7$ \\
\hline
\end{tabular}

1: Hydrogen peroxide $(0.5 \%)$ in drinking water for one month

2: Hydrogen peroxide $(0.5 \%)$ in drinking water for one month $+(1 \mathrm{mg}$ of lyophilized bee venom $+500 \mathrm{mg}$ of lyophilized royal jelly $+25 \mathrm{ml}$ honey $)(1 \mathrm{~g} / \mathrm{kg}$ orally) one month.

3: (1mg of lyophilized bee venom $+500 \mathrm{mg}$ of lyophilized royal jelly $+25 \mathrm{ml}$ honey) $(1 \mathrm{~g} / \mathrm{kg}$ orally) one month.

Data in Table (6) demonstrated that there was decrease in the percentage of the live sperms in hydrogen peroxide group (84) compared with control group (91.6). Treatment with $1 \mathrm{~g}$ (1mg of lyophilized 
bee venom $+500 \mathrm{mg}$ of lyophilized royal jelly $+25 \mathrm{ml}$ honey) $/ \mathrm{kg}$ of body weight orally concomitantly with hydrogen peroxide did not affect in the percentage of the live sperms compared with hydrogen peroxide group, Whereas the treatment with $1 \mathrm{~g}$ (1mg of lyophilized bee venom $+500 \mathrm{mg}$ of lyophilized royal jelly $+25 \mathrm{ml}$ honey) $/ \mathrm{kg}$ of body weight orally alone caused increase in the percentage of the live sperms and returned to normal control value. Data in the same Table revealed that increasing in the percentage of sperms deformity in hydrogen peroxide group compared with control group. Also treatment with $1 \mathrm{~g}$ ( $1 \mathrm{mg}$ of lyophilized bee venom $+500 \mathrm{mg}$ of lyophilized royal jelly $+25 \mathrm{ml}$ honey) $/ \mathrm{kg}$ of body weight orally with or without hydrogen peroxide caused decrease in the percentage of sperm deformity compared with hydrogen peroxide group. Data in the same Table showed decreasing in the testosterone hormone level in hydrogen peroxide group compared with control group. While, administration by $1 \mathrm{~g}$ (1mg of lyophilized bee venom +500mg of lyophilized royal jelly $+25 \mathrm{ml}$ honey) $/ \mathrm{kg}$ of body weight orally concomitant with or without hydrogen peroxide caused increase in testosterone hormone compared with hydrogen peroxide group, (Strum et al. 2002).

Table 6. Effect the treatment of $1 \mathrm{~g}$ ( $1 \mathrm{mg}$ of lyophilized bee venom $+500 \mathrm{mg}$ of lyophilized royal jelly $+25 \mathrm{ml}$ honey) $/ \mathrm{kg}$ of body weight orally on the percentage number of live sperm, sperm deformity, and testosterone hormone concentration in rats receiving hydrogen peroxide for one month (Mean $\pm \mathrm{SE})$..

$\begin{array}{llll}\text { Treated animals } & \text { Live Sperm\% } & \text { Sperm Deformity\% } & \text { Testosterone hormone }\end{array}$ $\mathbf{m g} / \mathbf{m l}$

\begin{tabular}{cccc}
\hline Control & $91.6 \pm 1.5$ & $4.2 \pm 0.37$ & $2.37 \pm 0.16$ \\
\hline $\mathbf{1}$ & $84 \pm 1.51$ & $11.2 \pm 1.06$ & $1.72 \pm 0.30$ \\
\hline $\mathbf{2}$ & $87 \pm 0.54$ & $9.0 \pm 7.03$ & $2.51 \pm 0.13$ \\
\hline $\mathbf{3}$ & $94.6 \pm 0.81$ & $4.6 \pm 0.4$ & $4.24 \pm 0.27$ \\
\hline
\end{tabular}

1: Hydrogen peroxide $(0.5 \%)$ in drinking water for one month.

2: Hydrogen peroxide $(0.5 \%)$ in drinking water for one month $+(1 \mathrm{mg}$ of lyophilized bee venom $+500 \mathrm{mg}$ of lyophilized royal jelly $+25 \mathrm{ml}$ honey $)(1 \mathrm{~g} / \mathrm{kg}$ orally) one month.

3: (1mg of lyophilized bee venom $+500 \mathrm{mg}$ of lyophilized royal jelly $+25 \mathrm{ml}$ honey) $(1 \mathrm{~g} / \mathrm{kg}$ orally) one month.

d. Effect of treatment by royal jelly and bee venom in Improve kidney function:

Data in Table (7\&8) show that oral administration with (1mg of lyophilized bee venom $+500 \mathrm{mg}$ of lyophilized royal jelly+25ml honey) orally in doses of $50 \mathrm{mg}$ and $100 \mathrm{mg} / \mathrm{kg}$ body weight increased urea concentration in serum and decreased in urine. Urea clearance in urine was also decreased as compared to control group.While, oral administration by (1mg of lyophilized bee venom $+500 \mathrm{mg}$ of lyophilized royal jelly+25ml honey) orally in a dose of $100 \mathrm{mg} / \mathrm{kg}$ body weight decreased serum and urine creatinine level which might be attributed to the increased cortisol level. (Abreu $\boldsymbol{e t}$ al. 2000).

Table 7. Effect of oral administration of 50 and $100 \mathrm{mg} / \mathrm{kg}$ body weight of $(1 \mathrm{mg}$ of lyophilized bee venom $+500 \mathrm{mg}$ of lyophilized royal jelly $+25 \mathrm{ml}$ honey) for 5 days on urea concentrations $(\mathrm{mg} / 100 \mathrm{ml})$ in serum and urine and urea clearance $(\mathrm{ml} / \mathrm{min})$ of rats $(\mathrm{n}=6)$

\begin{tabular}{|c|c|c|c|c|c|c|c|c|c|}
\hline \multirow[t]{3}{*}{ Groups } & \multicolumn{3}{|c|}{$\begin{array}{c}\text { Group (1) } \\
\text { Control }\end{array}$} & \multicolumn{3}{|c|}{$\begin{array}{c}\text { Group (2) } \\
(50 \mathrm{~m} / \mathrm{g} \mathrm{kg} \mathrm{b.} \mathrm{wt)} \\
\end{array}$} & \multicolumn{3}{|c|}{$\begin{array}{c}\text { Group (3) } \\
\text { (100 m/g kg b. wt) }\end{array}$} \\
\hline & \multicolumn{2}{|c|}{$\begin{array}{c}\text { Urea concentration } \\
(\mathrm{mg} \%)\end{array}$} & \multirow[t]{2}{*}{$\begin{array}{c}\text { Urea } \\
\text { clearance } \\
(\mathrm{mg} \%)\end{array}$} & \multicolumn{2}{|c|}{$\begin{array}{c}\text { Urea concentration } \\
(\mathrm{mg} \%)\end{array}$} & \multirow[t]{2}{*}{$\begin{array}{c}\text { Urea } \\
\text { clearance } \\
(\mathrm{mg} \%)\end{array}$} & \multicolumn{2}{|c|}{$\begin{array}{c}\text { Urea } \\
\text { concentration } \\
(\mathrm{mg} \%)\end{array}$} & \multirow[t]{2}{*}{$\begin{array}{c}\text { Urea } \\
\text { clearance } \\
(\mathrm{mg} \%)\end{array}$} \\
\hline & Serum & urine & & Serum & Urine & & Serum & Urine & \\
\hline Values & $\begin{array}{c}40.19 \pm \\
0.93\end{array}$ & $\begin{array}{c}145.00 \\
\pm \\
5.69\end{array}$ & $\begin{array}{c}0.019 \\
\pm \\
0.0007\end{array}$ & $\begin{array}{c}78.33 \\
\pm \\
1.60\end{array}$ & $\begin{array}{c}105.0 \\
\pm \\
5.54\end{array}$ & $\begin{array}{c}0.009 \\
\pm \\
0.0004\end{array}$ & $\begin{array}{c}88.28 \\
\pm \\
1.28\end{array}$ & $\begin{array}{c}46.33 \\
\pm \\
3.13\end{array}$ & $\begin{array}{c}0.0044 \\
\pm \\
0.0003\end{array}$ \\
\hline
\end{tabular}

$*$ Mean $\pm S E$

Table 8. Effect of oral administration of 50 and $100 \mathrm{mg} / \mathrm{kg}$ body weight of $(1 \mathrm{mg}$ of lyophilized bee venom $+500 \mathrm{mg}$ of lyophilized royal jelly $+25 \mathrm{ml}$ honey) for 5 days on creatinine level $(\mathrm{mg} \%)$ in serum and urine and creatinine clearance $(\mathrm{ml} / \mathrm{min})$ of rats $(\mathrm{n}=6)$

\begin{tabular}{|c|c|c|c|c|c|c|c|c|c|}
\hline \multirow{3}{*}{ 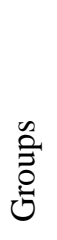 } & \multicolumn{3}{|c|}{$\begin{array}{l}\text { Group (1) } \\
\text { Control }\end{array}$} & \multicolumn{3}{|c|}{$\begin{array}{c}\text { Group (2) } \\
\text { (50m/g kg b. wt) }\end{array}$} & \multicolumn{3}{|c|}{$\begin{array}{c}\text { Group (3) } \\
(100 \mathrm{~m} / \mathrm{g} \mathrm{kg} \mathrm{b.} \mathrm{wt)}\end{array}$} \\
\hline & $\begin{array}{r}\text { Cre } \\
\text { conce } \\
(\mathrm{m} \\
\end{array}$ & $\begin{array}{l}\text { ine } \\
\text { ation } \\
\text { o) }\end{array}$ & $\begin{array}{c}\text { Greatinine } \\
\text { clearance } \\
(\mathrm{mg} \%)\end{array}$ & $\begin{array}{r}\text { Gre } \\
\text { concentr }\end{array}$ & ine $(\mathrm{mg} \%)$ & $\begin{array}{c}\text { Greatinie } \\
\text { clearance } \\
(\mathrm{mg} \%)\end{array}$ & $\begin{array}{r}\text { Gre } \\
\text { conce } \\
(\mathrm{m}\end{array}$ & $\begin{array}{l}\text { nine } \\
\text { ration } \\
\% \text { ) }\end{array}$ & $\begin{array}{c}\text { Greatinie } \\
\text { clearance } \\
(\mathrm{mg} \%)\end{array}$ \\
\hline & Serum & urine & & Serum & Urine & & Serum & Urine & \\
\hline
\end{tabular}




\begin{tabular}{|c|c|c|c|c|c|c|c|c|c|}
\hline$\stackrel{\vec{\pi}}{>} \approx$ & $\begin{array}{c}0.29 \\
\pm \\
0.015\end{array}$ & $\begin{array}{c}133.16 \\
\pm \\
4.00\end{array}$ & $\begin{array}{c}2.57 \\
\pm \\
0.0007\end{array}$ & $\begin{array}{c}0.30 \\
\pm \\
0.023\end{array}$ & $\begin{array}{c}120.68 \\
\pm \\
3.98\end{array}$ & $\begin{array}{c}2.89 \\
\pm \\
0.148\end{array}$ & $\begin{array}{c}0.22 \\
\pm \\
0.019\end{array}$ & $\begin{array}{c}88.75 \\
\pm \\
3.86\end{array}$ & $\begin{array}{c}0.0855 \\
\pm \\
0.050\end{array}$ \\
\hline
\end{tabular}

e. Effect of treatment by royal jelly and bee venom in glucose concentrations in serum and urine of rats( Diabetics Rats):

Decreasing in serum glucose level was also observed when the test animals were treated with (1mg of lyophilized bee venom $+500 \mathrm{mg}$ of lyophilized royal jelly $+25 \mathrm{ml}$ honey) orally in a dose of 50 and $100 \mathrm{mg} / \mathrm{kg}$ body weight (Table 9). Present findings suggest that (1mg of lyophilized bee venom $+500 \mathrm{mg}$ of lyophilized royal jelly $+25 \mathrm{ml}$ honey) possessed insulin like effects (Munstedt et al. 2009).

Table 9. effect of oral administration of 50 and $100 \mathrm{mg} / \mathrm{kg}$ body weight of $(1 \mathrm{mg}$ of lyophilized bee venom $+500 \mathrm{mg}$ of lyophilized royal jelly+25ml honey) for 5 days on glucose concentrations $(\mathrm{mg} / 100 \mathrm{ml})$ in serum and urine of rats $(n=6)$.

\begin{tabular}{ccccccc}
\hline \multirow{2}{*}{$\begin{array}{c}\text { Rats Group } \\
\text { No }\end{array}$} & \multicolumn{2}{c}{ Group (1) } & \multicolumn{2}{c}{ Group (2) } & \multicolumn{2}{c}{ Group (3) } \\
& \multicolumn{2}{c}{ Control } & (50 mg/kg .b. wt $)$ & Serum & Urine \\
\cline { 2 - 7 } & Serum & Urine & Serum & Urine & Sg .b. wt $)$ \\
\hline Values & $96.73^{*}$ & 0.00 & 88.42 & 0.00 & 84.14 & 0.00 \\
& \pm & & \pm & & \pm & \\
& 0.584 & & 0.766 & & 1.21 & \\
\hline
\end{tabular}

$*$ Mean $\pm S E$

\section{Reference}

A.O.A.C. (2005) Official Methods of Analysis. Association of Official Analytical, Che-mists $18^{\text {th }}$ ed., Washington, DC, USA.

Abdul-Rahman S.Y. (1995) Effect of starvation and experimental diabetes mellitus on glutathione and lipid peroxidation in tissues rats. Doctor's dissertation. College of Veterinary Medicine, University of Mosul, Iarq.

Abreu R.M.M.;Silva de Moraes R.L.M. and Malaspina O.(2000)Histological aspects and protein content of Apis mellifera L. worker venom glands: the effect of electrical shocks in summer and winter. Journal Venom Animal. Toxins.; 6, $87-98$.

Al-sadi A.A. (2001) Fertility and Artifical Insemination. 2nd ed College of Veterinary Medicine, University of Mosul.Iraq.

Al-Taei A.Y.J. (2003) Effect of vitamin C on some testicular function in rats exposed to oxidative stress induced by hydrogen peroxide. MSc. Thesis College of Veterinary Medicine, University of Mosul. Iraq.

American Apitherapy society. (2001). 5390 Grande road, Hillsboro, 45133. (937) 364-1108. http:// www. Apitherapy. Org/. Gale Encyclopedia of Alternative Medicine. Gale Group.

Antinelli J.; Zeggane S.; Davico R.; Rognone C.; Faucon J. and Lizzani L. (2003) Evaluation of (E)-10-hydroxydec-2-enoic acid as a freshnessparameter for royal jelly. Food Chem.; 80:85-89.

Bachanova K.; Klaudiny J.; Kopernicky J. and Simuth J. (2002) Identification of honeybee peptide active against Paenibacillus larvae larvae through bacterial growth-inhibition assay on polyacrylamide gel. Apidologie 33 (3): 259-269.

Bearden H.J.; Fuguany T.W. and Willard S.T. (2004) Applied animal reproduction. 6th ed Mississippi State University.

Beck B.F. (1999) "Bee Venom Therapy. New York: Appleton-Century 1935; by Schmidt and Buchmann" "In. The Hive and the Honey Bee, Edited by Joe M. Graham, Dadant and Sons, Hamilton, Illinois".

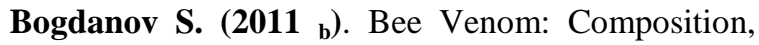
Health, Medicine : A Review . Bee product science 1-16. (http://www.bee-hexagon.net, 15 January 2012.)

Bogdanov S. (2011 $)$ ). Royal Jelly, bee brood: composition, health, medicine: A review. Bee product science 1-31. (http://www.beehexagon.net, 15 January 2012.)

Codex Alimentarius Comission (1989). Codex standards for sugards (honey).Supplement to codex Alimentarius volume III. Food and Agriculture Organization of the united Nations and world health organization, Rome.

Compston J.E. (2001)Sex steroids and bone. Physiol Review.8:419-447.

Crane E. (1990)"Bees and beekeeping": Science, Practice and World Resources. Cornstock Publication., Ithaca, NY., USA.; 593 pp,

D.G.H.C.P.: Directorate General Healthand Consumer Protection (2002) Implementation of Regulation (EC) No 258/97 of the European parliament and the council of $27^{\text {th }}$ January 1997 concerning novel foods and novel food ingredients. (SANCO D4) European Commission.

DzopalicT.; Vucevic D.; Tomic S.; Djokic J.; Chinou I.and Colic., M (2011) 10-Dihydroxy- 
decanoic acid, isolated from royal jelly, stimulates Th1 polarising capability of human monocyte-derived dendritic cells. Food Chemistry 126 (3): 1211-1217.

Ebisch I.M.W.; Pierik F.H.; Jong F.H.; Thomas C.M.G. and Steeger-Theunissen R.P.M. (2006) Does folic acid and zinc sulphate intervention affect endocrine parameters and sperm characteristics in men. International Journal Androl.;29(2):339-345.

El-Banby M.A. (1994) "Honeybees in the Koran and in medicine. Al-Ahram Centre for Translation and Publication, Cairo, Egypt; 268 pp, (In Arabic). [6] Health and the Honey.

Fang E.; Zhou. H.; Xu. H. and Xing. M. (1994) Antiulcer effects of 10-hydroxy-2-decenoic acid inrats. ZhongguoYaolixue Tongbao 10 (2): 9-42.

Habermann E. and Jentsch J. (1999) "Sequenzanalyse des Melittins aus den tryptischen und peptischen Spaltstiicken". HoppeSeyler's Z. Physiol. Chem. 348: 37-50, 1967."In. The Hive and the Honey Bee, Edited by Joe M. Graham, Dadant and Sons, Hamilton, Illinois, ").

Hattori N.; Nomoto H.; Fukumitsu H.; Mishima S. and Furukawa S. (2007) Royal jelly and its unique fatty acid, 10-hydroxy-trans-2-decenoic acid, promote neurogenesis by neural stem/progenitor cells in vitro. Biomed Res.;28(5):261-6.

http://www.apitherapy.org (2001).

http://www.bee-hexagon.net 15 January 2012.

http://www.goldinnature.com/apithera pylinks htm. Inter net. 2004.

Ito S.; Nitta Y.; Fukumitsu H.; Soumiya H.; Ikeno K.; Nakamura T. and Furukawa S. (2012) Antidepressant-Like Activity of 10-HydroxyTrans-2-Decenoic Acid, a Unique Unsaturated Fatty Acid of Royal Jelly, in Stress-Inducible Depression-Like Mouse Model. Evidence-based complementary and alternative medicine: 1-6.

Izuta H.; Chikaraishi Y.; Shimazawa M.; Mishima S. and Hara H. (2009) 10-Hydroxy-2decenoic Acid, a Major Fatty Acid from Royal Jelly, Inhibits VEGF-induced Angiogenesis in Human Umbilical Vein Endothelial Cells. Evidence-based complementary and alternative medicine 6 (4): 489-494.

Khattab M.M. (1997) Bee venom collection as new product from apiaries in Egypt. International symposium of apitherapy, March 8-9 $9^{\text {th }}, 1997$ of apitherapy center Eldoki. Cairo

Kim J.; Kim Y.; Yun H.; Park H.; Kim S.Y.; Lee K.G.; Han S. M. and Cho Y. (2010) Royal jelly enhances migration of human dermal fibroblasts and alters the levels of cholesterol and sphinganine in an in vitro wound healing model. Nutrition Research and Practice 4 (5): 362-368.

Kodai T.; Umebayashi K.; Nakatani T.; Ishiyama K.and Noda N. (2007) Compositions of royal jelly II. Organic acid glycosides and sterols of the royal jelly of honeybees (Apis mellifera). Chemical \& Pharmaceutical Bulletin 55 (10): 1528-1531.

Krell R. (1996) Value-added products from beekeeping. FAO Food and Agriculture Organization of the United Nations Roma; 409 pp

Lercker G.; Caboni M. F.; Vecchi M. A; Sabatini A.G. and Nanetti A. (1993) Caratterizzazione deiprincipali costituenti della gelatina reale. Apicoltura 8: 27-37.

Lercker, G. (2003). La gelatina reale: composizione, autenticità edadulterazione. In Atti del Convegno "Strategie per lavalorizzazione dei prodotti dell'alveare". Università degliStudi del Molise; Campobasso, 67-81.

Leung R.; Ho A. and Chan J. (1997) Royal jelly consumption and hypersensitivity in the community. Clin Exp Allergy.; 27:333-336.

Matsui T.; Yukiyoshi A.; Doi S.; Sugimoto H.; Yamada H. and Matsumoto K. (2002) Gastrointestinal enzyme production of bioactive peptides from royal jelly protein and their antihypertensive ability in SHR. Journal of nutritional biochemistry 13 (2): 80-86.

Messia, M.C., Caboni, M.F., Marconi, E. (2005). Storage stability assessment of freeze-dried royal jelly by furosine determination. Journal of agricultural and food chemistry, 53 (11):44404443.

Mishima S.; Suzuki K.; Isohama Y.; Kuratsu N.; Araki Y.; Inoue M. and Miyata T. (2005) Royal jelly has estrogenic effects in vitro and in vivo. J Ethnopharm.; 101:215-220.

Münstedt K.; Bargello M.; and Hauenschild A. (2009) Royal Jelly Reduces the Serum Glucose Levels in Healthy Subjects. Journal Med Food 12: 1170-1172.

NaritaY.; Nomura J.; Ohta S.; Inoh Y.; Suzuki K.M.; Araki Y.; Okada S.; Matsumoto I.; Isohama Y.; Abe K.; Miyata T. and Mishima S.(2006) Royal jelly stimulates bone formation: physiologic and nutrigenomic studies with mice and cell lines. Biosci Biotechnol Biochem;70(10):2508- 2514.

Norman A.R.; Cicero B.; Eloi S.G.M.; Tariq M.B. and Patricia A. (2011)"Insect natural products and processes: New treatments for human disease". Insect Biochemistry and Molecular Biology 41(10): 747-769,

Okuda H.; Kameda. K; Morimoto C.; Matsuura Y.; Chikaki M. and Ming J. (1998) Studies on insulinlike substances in royal jelly and other substances in royal jelly which inhibit angiotensin-converting enzyme. Honeybee Science 19 (1): 9-14.

Petrie A. and Watson P. (1999) Statistic for veterinary and animal science. Blackwell Publishing Company.

Sabatini, A.G., Marcazzan, G., Caboni, M.F., Bogdanov, S., Almeida-Muradian, L.B.( 2009). 
Quality. and standardisation of royal jelly. JAAS,

1: $1-6$.

Scarselli, R., Donadio, E., Giuffrida, M.G., Fortunato, D., Conti, A., Balestreri, E., Felicioli, R., Pinzauti, M., Sabatini, A.G., Felicioli, A. (2005). Towards royal jelly proteome.Proteomics, 5:769-776.

Schmidt J.O. and Buchmann S.L. (1999) "Other products of the hive" (In: The hive and the honeybee. Graham, J.M. ed. Dadant \& Sons, Hamilton, Illinois, USA. Fourth Printing 952960.

Simúth, J. 2001. Some properties of the main protein of honeybee(Apis mellifera) royal jelly.Apidologie, 32: 69-80.

Strum G.; Kranke B. and Rudolph C. (2002).Rush Hymenoptera venom immunotherapy; a safe and practical protocol for high-risk patients. J Allergy Clin Immunol 110(6) : 928-933.
Terada Y.; Narukawa M. and Watanabe T. (2011) Specific Hydroxy Fatty Acids in Royal Jelly Activate TRPA1. Journal of agricultural and food chemistry 59 (6): 2627-2635.

Tumanov A.A. and Osipova N.I. (1996) "Biological determination of traces of substances". Mat. All-Union Conf., 1963, Gorky, USSR, 238-246, 1966. In: Value-added products from beekeeping, Krell, R. (Ed.). FAO Agriculture Services Pulletin. Rome, Italy, pp: 227-240.

Urtubey N. (2005) Apitoxin: from bee venom to apitoxin for medical use. Termas de Rio Grande Santiago del Estero, Argentina.

World Health Organization. WHO (2002) Laboratory Manual for the Examination of Human Semen and Sperm-Cervical Mucus Interaction. 4thed Cambridge, United Kingdom: Cambridge University Press; 1999(Cited by; Saleh RA. Agarwal A. Oxidative stress and male infertility: From Research Bench to Clinical Practice. J Androl; 23 (6):737-752.

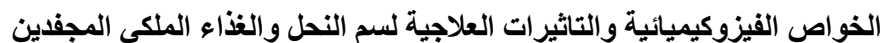

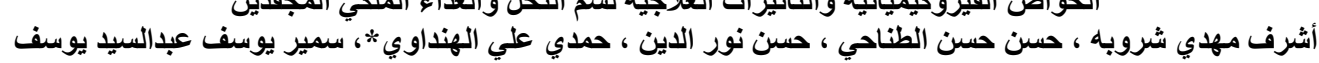

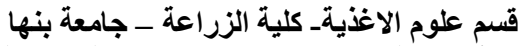

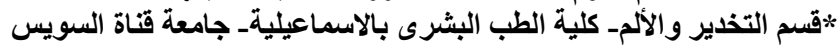

$$
\text { الملخص العربي }
$$

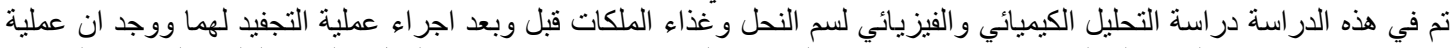

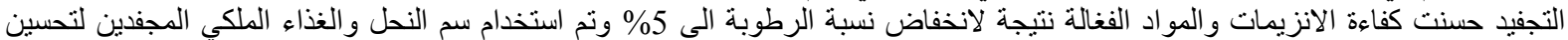

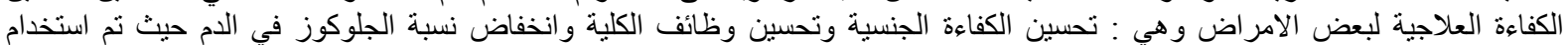

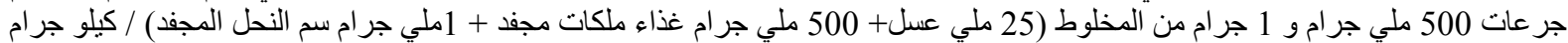

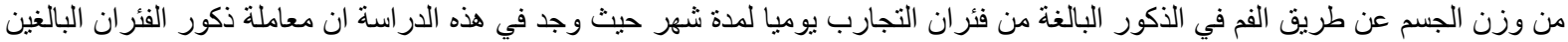

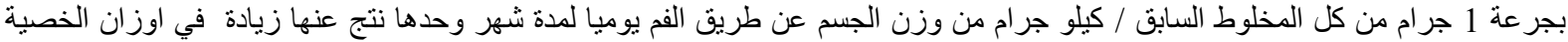

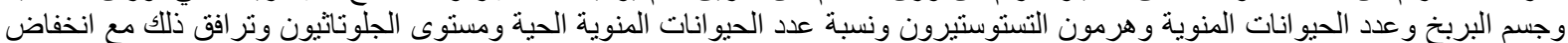

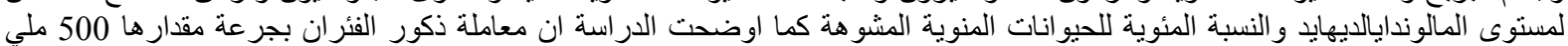

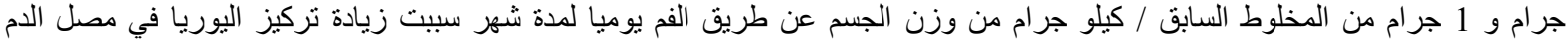

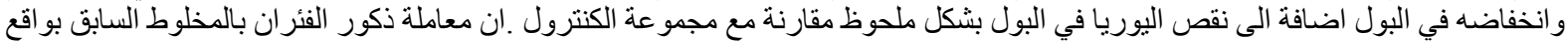

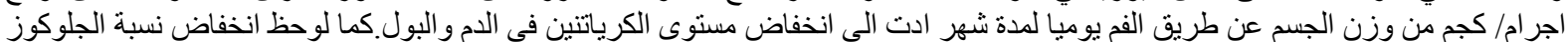

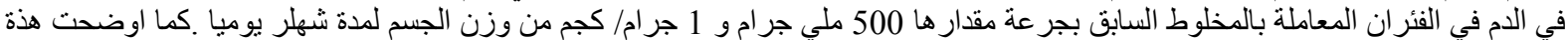

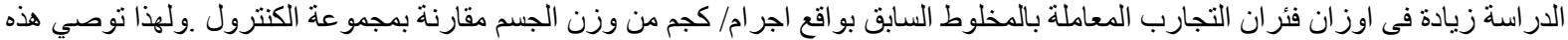
الدر اسة باستخدام مخاليط سم النحل المجفد و الغذاء الملكي المجفد المذابان في عسل النحل في علاج الكل الكفاءة الجنسية والكلى ومرض السكر. 